\title{
Biodegradation of benzotriazoles and hydroxy-benzothiazole in wastewater by activated sludge and moving bed biofilm reactor systems
}

\author{
Mazioti, Aikaterini A.; Stasinakis, Athanasios S.; Pantazi, Ypapanti ; Andersen, Henrik Rasmus
}

Published in:

Bioresource Technology

Link to article, DOI:

10.1016/j.biortech.2015.06.035

Publication date:

2015

Document Version

Peer reviewed version

Link back to DTU Orbit

Citation (APA):

Mazioti, A. A., Stasinakis, A. S., Pantazi, Y., \& Andersen, H. R. (2015). Biodegradation of benzotriazoles and hydroxy-benzothiazole in wastewater by activated sludge and moving bed biofilm reactor systems. Bioresource Technology, 192, 627-635. https://doi.org/10.1016/j.biortech.2015.06.035

\section{General rights}

Copyright and moral rights for the publications made accessible in the public portal are retained by the authors and/or other copyright owners and it is a condition of accessing publications that users recognise and abide by the legal requirements associated with these rights.

- Users may download and print one copy of any publication from the public portal for the purpose of private study or research.

- You may not further distribute the material or use it for any profit-making activity or commercial gain

- You may freely distribute the URL identifying the publication in the public portal 
This is a post-print of the manuscript Biodegradation of benzotriazoles and hydroxy-benzothiazole in wastewater by activated sludge and moving bed biofilm reactor systems. Bioresource Technology. Volume 192, September 2015, Pages 627-635 The publishers version is available from: http://dx.doi.org/10.1016/j.biortech.2015.06.035.

\section{Biodegradation of benzotriazoles and hydroxy- benzothiazole in wastewater by activated sludge and moving bed biofilm reactor systems}

Aikaterini A. Mazioti ${ }^{\mathrm{a}}$, Athanasios S. Stasinakis ${ }^{\mathrm{a}, \mathrm{b}^{*}}$,Ypapanti Pantazi ${ }^{\mathrm{a}}$, Henrik R. Andersen ${ }^{\mathrm{b}}$ ${ }^{a}$ Department of Environment, University of the Aegean, Mytilene, Greece

${ }^{\mathrm{b}}$ Department of Environmental Engineering, Technical University of Denmark, Miljøvej, B 113, 2800 Kgs. Lyngby, Denmark.

*Corresponding author. Tel.: +30 22510 36257; fax: +30 22510 36206; astas@env.aegean.gr

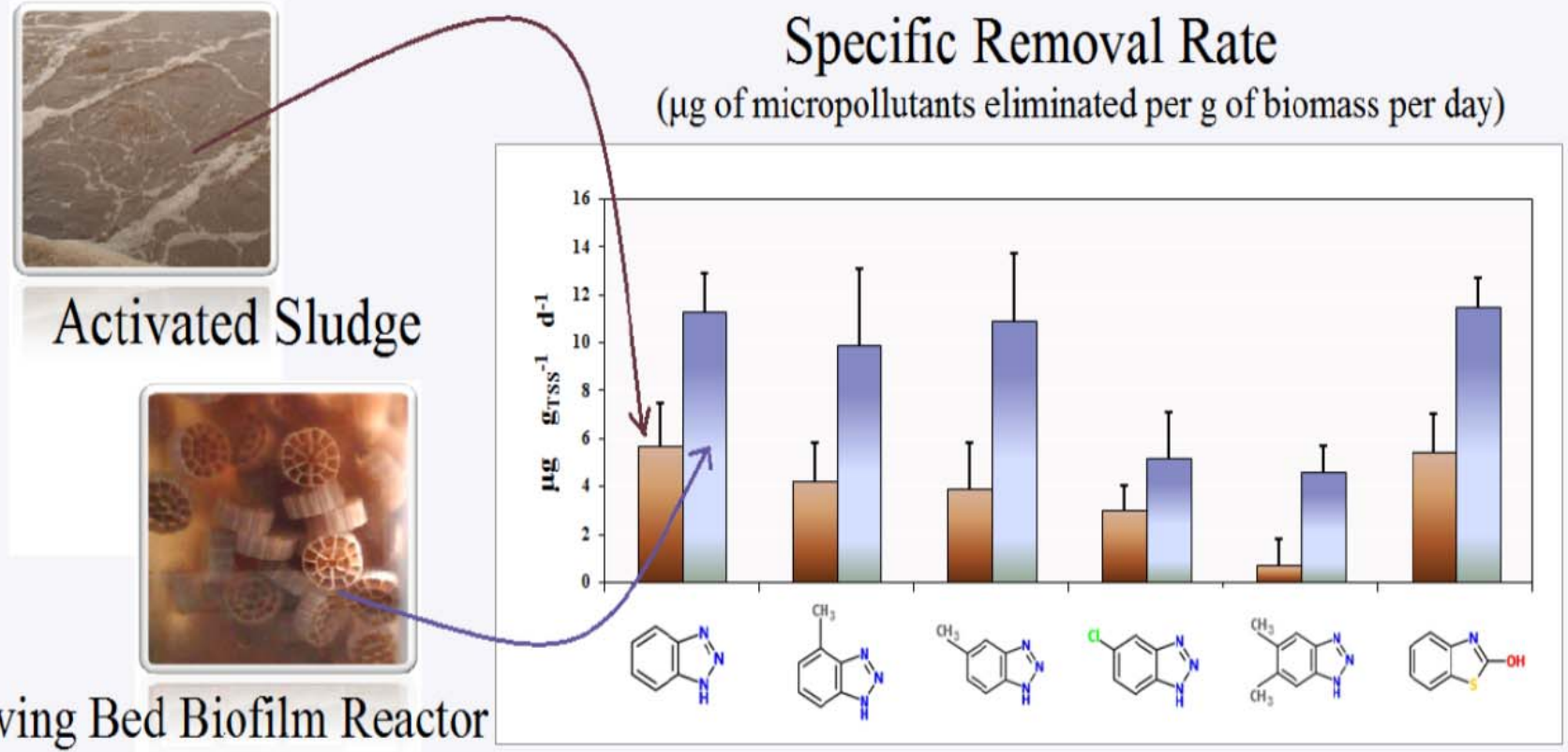

Moving Bed Biofilm Reactor

\section{Highlights}

$>$ All target compounds were biodegradable in both Activated Sludge and MBBR systems

Operation of MBBR at low organic loading enhanced micropollutants removal

Attached biomass exhibited greater ability to remove micropollutants

Biodegradation potential in biofilm differed in each bioreactor of MBBR system

Biodegradation of micropollutants occurs due to cometabolic phenomena 


\section{ABSTRACT}

Two laboratory scale fully aerated continuous flow wastewater treatment systems were used to compare the removal of five benzotriazoles and one benzothiazole by suspended and attached growth biomass. The Activated Sludge system was operated under low organic loading conditions. The Moving Bed Biofilm Reactor (MBBR) system consisted of two serially connected reactors filled with K3-biocarriers. It was either operated under low or high organic loading conditions. Target compounds were removed partially and with different rates in tested systems. For MBBR, increased loading resulted in significantly lower biodegradation for 4 out of 6 examined compounds. Calculation of specific removal rates (normalised to biomass) revealed that attached biomass had higher biodegradation potential for target compounds comparing to suspended biomass. Clear differences in the biodegradation ability of attached biomass grown in different bioreactors of MBBR systems were also observed. Batch experiments showed that micropollutants biodegradation by both types of biomass is co-metabolic.

Keywords: Biocarriers; MBBR; co-metabolism; kinetics; micropollutants. 
This is a post-print of the manuscript Biodegradation of benzotriazoles and hydroxy-benzothiazole in wastewater by activated sludge and moving bed biofilm reactor systems. Bioresource Technology. Volume 192, September 2015, Pages 627-635 The publishers version is available from: http://dx.doi.org/10.1016/j.biortech.2015.06.035.

\section{Introduction}

Benzotriazoles (BTRs) and benzothiazoles (BTHs) are two classes of polar emerging contaminants that are frequently detected in surface water all over the world (Ni et al., 2008; Loos et al., 2009; Nödler et al., 2014). Due to their widespread use in several industrial applications and everyday products (anticorrosive and antifreezing products, drugs, ultraviolet stabilizers), sewage is considered their main pathway to the aquatic environment and concentrations up to some $\mu \mathrm{g} \mathrm{L}^{-1}$ are frequently detected (Liu et al., 2012; Thomaidis et al., 2012; Stasinakis et al., 2013).

According to monitoring studies conducted in full-scale Sewage Treatment Plants (STPs), BTRs and BTHs are partially removed during conventional wastewater treatment (Reemtsma et al., 2010; Stasinakis et al., 2013). Some recent studies have focused on the aerobic biodegradation rates of these compounds in activated sludge (AS) batch experiments, while continuous-flow experiments have so far not been performed to investigate their removal in AS systems. Specifically, Liu et al. (2011) investigated biodegradation of benzotriazole (BTR), 5-methy-1H-lbenzotriazole (5TTR) and 5chlorobenzotriazole (CBTR) in batch experiments conducted under different conditions and calculated their kinetic parameters, while Huntscha et al. (2014) calculated half-lives and biotransformation products of selected BTRs. Herzog et al. (2014a, b) studied the removal efficiency of BTR, 4-methyl-1H-benzotriazole (4TTR) and 5TTR under different experimental conditions and reported that sludge acclimatization enhanced biodegradation of some compounds. In a recent study focusing on biodegradation and sorption, Mazioti et al. (2015) reported that BTR, CBTR, xylytriazole (XTR), and 2-hydroxybenzothiazole $(\mathrm{OHBTH})$ can be biodegraded by AS with half-lives varying from 6.5 hours to 47 hours, while sorption contributes weakly to their elimination.

Concerning biological wastewater treatment, a novel type of treatment has been developed by the late 1980s in Norway (Barwal and Chaudhary, 2014). This type of treatment profited of the microorganisms trend to form biofilms and is nowadays giving a promising option for wastewater treatment. Moving Bed Biofilm Reactor (MBBR) systems have been used both in pilot plant studies and in full scale plants for the treatment of different types of wastewater (Barwal and Chaudhary, 2014). MBBRs are usually filled with plastic biocarriers, on which biomass is attached, and circulate in all parts of the reactor with the aid of aeration or mechanical stirring. Some of the attached biomass advantages are their ability to cope with high loading conditions, the capacity of treatment of both industrial and municipal wastewater at a relatively low footprint and the avoidance of excess sludge removal (Loupasaki and Diamadopoulos, 2013; Shahot et al., 2014). Due to these advantages attached biomass presents, many previous studies have focused on the operation of MBBRs pilot systems investigating the removal of conventional pollutants from sewage (Di Trapani et al., 2011; Ibrahim et al., 2014; Zhang et al. 2014 and Gilbert at al., 2014). On the other hand, though biofilms may be a key technology for the removal of toxic and emerging pollutants (Borghei et al., 2004; Edwards and Kjellerup, 2013), only few studies have examined the removal of micropollutants using MBBRs. Specifically, Falås et al. (2012) investigated pharmaceuticals degradation and calculated removal rate constants in batch experiments with carriers that had been collected from different fullscale STPs, while in a recent work they investigated the removal of 20 micropollutants by monitoring a full scale hybrid biofilm/AS plant (Falås et al., 2013). In another study, the removal of three hormones was examined by early-stage biofilm in batch tests (Khan et al., 
This is a post-print of the manuscript Biodegradation of benzotriazoles and hydroxy-benzothiazole in wastewater by activated sludge and moving bed biofilm reactor systems. Bioresource Technology. Volume 192, September 2015, Pages 627-635 The publishers version is available from: http://dx.doi.org/10.1016/j.biortech.2015.06.035.

2013). Luo et al. (2014) operated a bench-scale MBBR system with polyurethane sponge carriers in order to determine various micropollutants removal. Finally, Accinelli et al. (2012) examined the removal of bisphenol-A, atrazine and oseltamivir with bioplastic carriers inoculated with specific bacterial strains. Concerning BTRs and BTHs, so far their removal in MBBR systems has not been studied and their biodegradation constants have not been calculated using attached biomass. Moreover, to the best of our knowledge, no studies are available comparing the ability of suspended and attached biomass to remove micropollutants. Limited information is also available for the role of organic loading (Ahmadi et al., 2015) and the contribution of different reactors in series on micropollutants removal in a MBBR system.

Based on the above, the main objective of this study was to examine two different types of biological treatment (AS and MBBR) in order to compare their ability to remove BTR, CBTR, XTR, 4TTR, 5TTR and OHBTH from domestic wastewater. For this reason, two continuous-flow laboratory scale systems were installed and operated under different hydraulic retention time (HRT). Both systems were monitored during adequate period of time for the elimination of conventional wastewater parameters and target micropollutants and the specific removal rates (as $\mu \mathrm{g}$ of compound per gram of biomass and day) were calculated for each target micropollutant. Special focus was given on the contribution of different bioreactors of MBBR system on the removal of micropollutants and on the biodegradation potential of developed biomass in different bioreactors. Batch experiments were also conducted using AS and biomass from MBBR systems in order to determine the role of organic substrate, measured as chemical oxygen demand (COD) on biodegradation kinetics. The calculated biodegradation constants were used in order to predict the removal of target compounds in applied systems and consequently evaluate their accuracy.

\section{Materials and Methods}

\subsection{Analytical standards and reagents}

Analytical standards of XTR and CBTR were supplied by Sigma-Aldrich (USA). BTR was purchased from Merck (Germany), 4TTR by Fluka (Switzerland), 5TTR by Acros Organics (Belgium); whereas OHBTH was purchased from Alfa Aesar (USA). Stock solutions of individual compounds were prepared in methanol $(\mathrm{MeOH})$ at $1000 \mathrm{mg} \mathrm{L}^{-1}$ and kept at $-18{ }^{\circ} \mathrm{C}$. Working solutions of $10 \mathrm{mg} \mathrm{L}^{-1}$ were prepared when needed and were kept at $-18{ }^{\circ} \mathrm{C}$ for a time period not exceeding three months. Methanol (MeOH; HPLC-MS grade) and acetonitrile (ACN; HPLC grade) were purchased from Merck (Germany) and Fisher (USA), respectively. The solid phase extraction (SPE) cartridges used for samples' clean-up were polymer-based with surface modified styrene divinylbenzene phase (StrataX, 33u Polymeric Reversed Phase $200 \mathrm{mg} / 6 \mathrm{ml}$ ) and they were supplied by Phenomenex (USA). HPLC grade water was prepared in the laboratory using a MilliQ/MilliRO Millipore system (USA). Ultra-pure $\mathrm{HCl}$ (32\%), used for samples acidification, was purchased from Merck (Germany).

\subsection{Continuous flow systems: set-up and operation}

Small scale continuous flow systems were installed and operated in the laboratory (Figure S1), under constant room temperature controlled by central air-conditioning system. The AS system consisted of an aerobic bioreactor (AB), with a working volume of $4.5 \mathrm{~L}$, and a settling tank with a working volume of $1 \mathrm{~L}$, from which sludge was recirculating to the bioreactor (Solid Retention Time, SRT: $18 \mathrm{~d}$; HRT: $26.4 \pm 2.4$ h; organic loading: 0.25 
This is a post-print of the manuscript Biodegradation of benzotriazoles and hydroxy-benzothiazole in wastewater by activated sludge and moving bed biofilm reactor systems. Bioresource Technology. Volume 192, September 2015, Pages 627-635 The publishers version is available from: http://dx.doi.org/10.1016/j.biortech.2015.06.035.

$\left.\pm 0.16 \mathrm{~kg} \mathrm{~m}^{-3} \mathrm{~d}^{-1}\right)$. The AS for AB start-up was taken from a nitrifying municipal STP (Mytilene, Greece), operating at a SRT of $18 \mathrm{~d}$; the laboratory scale system operated in summer 2014. The MBBR system consisted of two aerobic bioreactors (BC1 and BC2) connected in series, with a working volume of $4.5 \mathrm{~L}$ each. Each bioreactor contained biocarriers (type K3, AnoxKaldnes) at a filling ratio of 30\%. The biocarriers were moving due to aeration in all parts of the reactor. The MBBR system was operated at two HRTs, in two different experimental cycles during summer and autumn 2014. A HRT of $26.4 \pm 3.6 \mathrm{~h}$ (for each reactor) was applied in the first experimental cycle, providing a low substrate organic loading (MBBR-low) equal to $0.25 \pm 0.16 \mathrm{~kg} \mathrm{~m}^{-3} \mathrm{~d}^{-1}$ for BC1 and $0.05 \pm 0.03 \mathrm{~kg} \mathrm{~m}^{-}$ ${ }^{3} \mathrm{~d}^{-1}$ for BC2. A lower HRT of $10.8 \pm 1.2 \mathrm{~h}$ (for each reactor) was applied in the second experimental cycle in order to provide higher substrate organic loading (MBBR-high), equal to $0.60 \pm 0.40 \mathrm{~kg} \mathrm{~m}^{-3} \mathrm{~d}^{-1}$ for BC1 and $0.17 \pm 0.11 \mathrm{~kg} \mathrm{~m}^{-3} \mathrm{~d}^{-1}$ for BC2. All systems were fed with raw wastewater collected from the STP of the University Campus in Mytilene, Greece (Table S1). In all bioreactors, the conservation of aerobic conditions and adequate mixing of biomass were achieved by using porous ceramic diffusers, while dissolved oxygen concentration (DO) was higher than $4 \mathrm{mg} \mathrm{L}^{-1}$. In order to develop a stable biofilm onto the carriers, the MBBR system was operated for 5 months with domestic wastewater before starting the experiments with micropollutants.

An acclimatization phase of 3 to 4 weeks took place for both systems, during which conventional pollutants removal was frequently examined in order to ensure AS and MBBRs stability and efficient performance. After this period of time, the target compounds were spiked using methanol solutions, in order to obtain a daily stable concentration inflow of approximately $20 \mu \mathrm{g} \mathrm{L}^{-1}$. In order to evaluate the removal of target compounds, samples were taken for 10 consecutive days from different sampling points of the systems (Figure S1). To control the operation of continuous-flow systems, $\mathrm{COD}, \mathrm{NH}_{4}-\mathrm{N}, \mathrm{NO}_{3}-\mathrm{N}$, Mixed Liquor Suspended Solids (MLSS), Total Suspended Solids (TSS), attached biomass onto biocarriers, temperature $(\mathrm{T}), \mathrm{DO}$ and $\mathrm{pH}$ were measured at predetermined time intervals.

\subsection{Batch biodegradation experiments}

To calculate biodegradation kinetics of target compounds and to investigate the effect of organic substrate availability on their biodegradation, batch experiments were also conducted with both types of biomass. AS was collected from a nitrifying STP (Mytilene, Greece) during autumn 2014, while attached biomass was used from the second MBBR experimental cycle (MBBR-high) that was running that period. AS experiments were conducted in stoppered glass bottles that were constantly agitated on a shaking plate. The working volume in each reactor was $1 \mathrm{~L}$ and the mixed liquor suspended solids (MLSS) concentration was equal to $3000 \pm 200 \mathrm{mg} \mathrm{L}^{-1}$. Experiments with attached biomass were conducted in the bioreactors (BC1, BC2) by stopping the flow and operating them under batch conditions for $24 \mathrm{~h}$. The investigated compounds were spiked using methanolic solutions to obtain an initial concentration of approximately $30 \mu \mathrm{g} \mathrm{L}^{-1}$ for each microcontaminant in the reactors. Two different COD concentrations were tested $\left(30 \mathrm{mg} \mathrm{L}^{-}\right.$ ${ }^{1}$ and $270 \mathrm{mg} \mathrm{L}^{-1}$ ), corresponding to a low and moderate organic loading of $0.03 \mathrm{~kg} \mathrm{~m}^{-3} \mathrm{~d}^{-1}$ and $0.27 \mathrm{~kg} \mathrm{~m}^{-3} \mathrm{~d}^{-1}$, respectively. To quantify biodegradation of micropollutants, homogenized samples (50 mL) were collected after 0, 1, 2.5, 5, 12 and 24 hours. Since sorption to organic matter is of minor importance for these groups of compounds (Mazioti et al., 2015), the concentrations of target compounds were determined only in the dissolved 
This is a post-print of the manuscript Biodegradation of benzotriazoles and hydroxy-benzothiazole in wastewater by activated sludge and moving bed biofilm reactor systems. Bioresource Technology. Volume 192, September 2015, Pages 627-635 The publishers version is available from: http://dx.doi.org/10.1016/j.biortech.2015.06.035.

phase using the analytical method described below. All batch experiments were conducted at $22.0 \pm 0.5^{\circ} \mathrm{C}, \mathrm{pH}$ ranged between 6.3 and 7.4, while DO was higher than $4 \mathrm{mg} \mathrm{L}^{-1}$.

\subsection{Analytical methods}

Analysis of COD, $\mathrm{NH}_{4}-\mathrm{N}, \mathrm{NO}_{3}-\mathrm{N}$, TSS and MLSS were performed according to Standard Methods (APHA, 1998), T, DO and $\mathrm{pH}$ were measured using portable instruments. The quantification of the attached biomass occurred by removing the biofim from biocarriers and measuring the dried weight difference, as described by Falås et al., 2012. Microscopic observations were also conducted in order to check AS process (Jenkins and al. 2003) and biofilm formation.

For the investigation of target compounds fate, samples were filtered through glass fiber filters (GF-3 Macherey Nagel). Filtrates were collected, acidified to $\mathrm{pH} 3.0 \pm 0.1$ and stored at $4{ }^{\circ} \mathrm{C}$ until analysis. Analysis of target compounds in the dissolved phase was based on previously developed methods (Asimakopoulos et al., 2013; Mazioti et al. 2015) and included solid phase extraction (SPE). Chromatographic analysis was performed by a Shimatzu (Japan) LC20-AD prominence liquid chromatographer associated with a SPDM20A prominence diode array detector and a SIL-20AC auto sampler. Satisfactory recoveries and precision of the analytical procedure was achieved; whereas the obtained LODs ranged from $17 \mathrm{ng} \mathrm{L}^{-1}$ (BTR) to $125 \mathrm{ng} \mathrm{L}^{-1}$ (CBTR). Further information for the analytical method and the chromatographic conditions can be found in a recently published study (Mazioti et al., 2015).

\subsection{Equations}

Micropollutants removal in laboratory scale reactors was calculated according to Eq. (1):

$$
\text { Removal }=\left(1-\frac{C_{\text {out }}}{C_{\text {in }}}\right) \times 100
$$

Where $C_{i n}$ is the concentration of target compound in influent wastewater $\left(\mu \mathrm{g} \mathrm{L}^{-1}\right)$ and $C_{\text {out }}$ the concentration in treated wastewater of each examined reactor $\left(\mu \mathrm{g} \mathrm{L}{ }^{-1}\right)$.

Specific removal rate for each compound and type of biomass was calculated according to Eq.(2):

Specific Removal Rate $=\left(\frac{C_{\text {in }} Q_{\text {in }}-C_{\text {out }} Q_{\text {out }}}{X \times V}\right)$

Where $Q_{\text {in }}$ and $Q_{\text {out }}$ the flow rates of influent and effluent wastewater, respectively $\left(\mathrm{L} \mathrm{d}^{-}\right.$ $\left.{ }^{1}\right), X$ the concentration of attached or suspended biomass $\left(\mathrm{g} \mathrm{L}^{-1}\right)$ and $V$ the volume of each bioreactor (L).

The biodegradation rate constants $(k)$ were estimated using first order kinetics. Pseudo

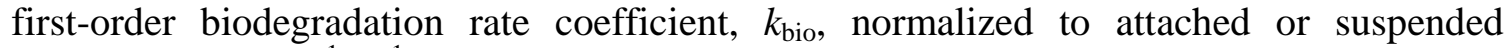
biomass ( $\mathrm{L} \mathrm{g} \mathrm{gLss}^{-1} \mathrm{~d}^{-1}$ ) was calculated for each biodegradation experiment using the appropriate sorption constant $\left(\mathrm{K}_{\mathrm{d}}\right.$ as $\left.\mathrm{L} \mathrm{g}^{-1}\right)$ for each compound (Mazioti et al. 2015) and Eq. (3) (Ziels et al. 2014):

$\ln \frac{C_{t}}{C_{0}}=-k_{\text {bio }} \times\left(\frac{X}{1+K_{d} X}\right) \times t$

Where $\mathrm{C}_{\mathrm{t}}$ and $\mathrm{C}_{0}$ are the dissolved target compound concentrations in batch experiment at time $\mathrm{t}$ and $\mathrm{t}=0$, respectively, $\left(\mu \mathrm{g} \mathrm{L}^{-1}\right)$.

Predicted removal in continuous-flow systems was estimated using the first-order biodegradation rate constants $(k)$ calculated in batch experiments, according to equation was 4: 
This is a post-print of the manuscript Biodegradation of benzotriazoles and hydroxy-benzothiazole in wastewater by activated sludge and moving bed biofilm reactor systems. Bioresource Technology. Volume 192, September 2015, Pages 627-635 The publishers version is available from: http://dx.doi.org/10.1016/j.biortech.2015.06.035.

$$
\text { Predicted Removal }=1-\left(\frac{1}{\left(1+k_{1} \tau_{1}\right)\left(1+k_{2} \tau_{2}\right)}\right)
$$

Where $\tau$ is the hydraulic retention time for each reactor; in the case of the MBBR system $\left(\tau_{1}, \tau_{2}\right)$, while for the AS system only one reactor was used $\left(\tau_{1}\right)$.

\subsection{Statistical analysis}

In order to compare the removal values and specific removal rates one-way ANOVA was used with Tukey-Kramers post-test for significant differences between groups.

\section{Results and Discussion}

\subsection{Operation of continuous-flow AS and MBBR systems}

The operational parameters of the continuous flow systems are presented in Table 1. Both systems adequately eliminated organic loading from wastewater, achieving similar average dissolved COD removal equal to 86\% (MBBR-low) and 90\% (AS). Both systems were also able to remove $\mathrm{NH}_{4}-\mathrm{N}$ sufficiently (average removal 93 - 95\%). During microscopic observations, protozoa, rotifers and filamentous bacteria were identified in the AS system, indicating a stable and mature environment (Jenkins et al., 2003). Metazoa and protozoa were also observed in the MBBR system (Figure S2). In the AS system, MLSS decreased slightly during the acclimatization phase, but the concentration remained stable $\left(2230 \pm 290 \mathrm{mg} \mathrm{L}^{-1}\right)$ during the experiment with micropollutants. In the MBBR system, a thicker biofilm and a higher concentration of biomass developed in the first bioreactor, BC1 (Table 1; Figure S3), probably due to the higher COD concentrations in BC1 comparing to BC2, where most organic substrate had already been consumed. Despite the thinner biofilm in BC2, the developed biomass had a greater ability to nitrify. In the first experimental cycle (low loaded MBBR), on average $170 \mathrm{mg}$ of $\mathrm{NH}_{4}-\mathrm{N}$ were removed per day and per gram of biomass in BC1, while $250 \mathrm{mg} \mathrm{d}^{-1} \mathrm{~g}^{-1}$ were removed in BC2. A similar trend was also observed during the second experimental cycle (high loaded MBBR), with nitrification rates being even higher in both reactors (on average $295 \mathrm{mg} \mathrm{d}^{-1} \mathrm{~g}^{-1}$ in BC1 and $480 \mathrm{mg} \mathrm{d}^{-1}$ $\mathrm{g}^{-1}$ in BC2). Furthermore, in the high loaded MBBR system, a thicker biofilm was observed in both bioreactors. 
This is a post-print of the manuscript Biodegradation of benzotriazoles and hydroxy-benzothiazole in wastewater by activated sludge and moving bed biofilm reactor systems. Bioresource Technology. Volume 192, September 2015, Pages 627-635

The publishers version is available from: http://dx.doi.org/10.1016/j.biortech.2015.06.035.

Table 1. Operational parameters of continuous flow systems, during acclimatization and loading with target compounds: Activated Sludge (AS, HRT $26.4 \pm 2.4$ hours), Biocarriers under low loading conditions (MBBR-low, HRT $26.4 \pm 3.6$ hours for each reactor) and Biocarriers under high loading conditions (MBBRhigh, HRT $10.8 \pm 1.2$ hours for each reactor).

\begin{tabular}{|c|c|c|c|c|c|c|c|c|c|c|c|c|c|}
\hline \multicolumn{14}{|c|}{$\begin{array}{c}\text { Activated Sludge System } \\
\end{array}$} \\
\hline \multirow{3}{*}{$\begin{array}{l}\text { Continuous } \\
\text { flow system }\end{array}$} & \multirow{3}{*}{$\begin{array}{c}\text { Days of } \\
\text { operation }\end{array}$} & & & MLSS (mg & TSS & \multirow{2}{*}{\multicolumn{2}{|c|}{$\mathrm{pH}$}} & \multicolumn{6}{|c|}{ Removal \% } \\
\hline & & & & & $\left(\mathrm{mg} \mathrm{L}^{-1}\right)$ & & & \multirow{2}{*}{\multicolumn{3}{|c|}{$\frac{\text { COD dissolved }}{\mathrm{AB}}$}} & \multirow{2}{*}{\multicolumn{3}{|c|}{$\frac{\mathrm{NH}_{4}-\mathrm{N}}{\mathrm{AB}}$}} \\
\hline & & & & $\mathrm{AB}^{1}$ & Out $^{2}$ & $\mathrm{AB}^{1}$ & Out $^{2}$ & & & & & & \\
\hline $\begin{array}{c}\text { AS } \\
(n=16)\end{array}$ & 31 & & & $\begin{array}{c}2370 \\
( \pm 590)\end{array}$ & $\begin{array}{c}11 \\
( \pm 13)\end{array}$ & $\begin{array}{c}7.2 \\
( \pm 0.4)\end{array}$ & $\begin{array}{c}7.3 \\
( \pm 0.6)\end{array}$ & \multicolumn{3}{|c|}{$90( \pm 7)$} & \multicolumn{3}{|c|}{$93( \pm 12)$} \\
\hline \multicolumn{14}{|c|}{ Moving Bed Bioreactor System } \\
\hline \multirow{3}{*}{$\begin{array}{l}\text { Continuous } \\
\text { flow system }\end{array}$} & \multirow{3}{*}{$\begin{array}{c}\text { Days of } \\
\text { operation }\end{array}$} & \multirow{2}{*}{\multicolumn{2}{|c|}{$\begin{array}{l}\text { Attached Biomass (mg } \\
\mathrm{L}^{-1} \text { ) }\end{array}$}} & MLSS & \multirow{3}{*}{$\begin{array}{c}\begin{array}{c}\text { MLSS } \\
\left(\mathrm{mg} \mathrm{L}^{-1}\right)\end{array} \\
\text { BC2 }^{4}\end{array}$} & \multirow{2}{*}{\multicolumn{2}{|c|}{$\mathrm{pH}$}} & \multicolumn{6}{|c|}{ Removal \% } \\
\hline & & & & $\left(\mathrm{mg} \mathrm{L}^{-1}\right)$ & & & & \multicolumn{3}{|c|}{ COD dissolved } & \multicolumn{3}{|c|}{$\mathrm{NH}_{4}-\mathrm{N}$} \\
\hline & & $\mathrm{BC}^{3}$ & $\mathrm{BC}^{4}$ & $\mathrm{BC}^{3}$ & & $\mathrm{BC}^{3}$ & $\mathrm{BC}^{4}$ & $\mathrm{BC}^{3}$ & $\mathrm{BC}^{4}$ & Total $^{5}$ & $\mathrm{BC}^{3}$ & $\mathrm{BC}^{4}{ }^{4}$ & Total $^{5}$ \\
\hline $\begin{array}{l}\text { MBBR-low } \\
(\mathrm{n}=15)\end{array}$ & 45 & $726^{6}$ & $100^{6}$ & $\begin{array}{c}195 \\
( \pm 81)\end{array}$ & $\begin{array}{c}131 \\
( \pm 89)\end{array}$ & $\begin{array}{c}7.0 \\
( \pm 0.5)\end{array}$ & $\begin{array}{c}6.8 \\
( \pm 0.9)\end{array}$ & $\begin{array}{c}81 \\
( \pm 13)\end{array}$ & $\begin{array}{c}42 \\
( \pm 26)\end{array}$ & $\begin{array}{c}86 \\
( \pm 11)\end{array}$ & $\begin{array}{c}78 \\
( \pm 29)\end{array}$ & $\begin{array}{c}84 \\
( \pm 23)\end{array}$ & $\begin{array}{c}93 \\
( \pm 13)\end{array}$ \\
\hline $\begin{array}{l}\text { MBBR-high } \\
\quad(\mathrm{n}=11)\end{array}$ & 45 & $\begin{array}{c}1079^{7} \\
( \pm 715)\end{array}$ & $\begin{array}{c}312^{7} \\
( \pm 108)\end{array}$ & $\begin{array}{l}138 \\
( \pm 68)\end{array}$ & $\begin{array}{c}124 \\
( \pm 68)\end{array}$ & $\begin{array}{c}7.4 \\
( \pm 0.2)\end{array}$ & $\begin{array}{c}7.2 \\
( \pm 0.3)\end{array}$ & $\begin{array}{c}72 \\
( \pm 11)\end{array}$ & $\begin{array}{c}67 \\
( \pm 21)\end{array}$ & $\begin{array}{c}91 \\
( \pm 7)\end{array}$ & $\begin{array}{c}73 \\
( \pm 24)\end{array}$ & $\begin{array}{c}87 \\
( \pm 21)\end{array}$ & $\begin{array}{c}95 \\
( \pm 7)\end{array}$ \\
\hline
\end{tabular}

${ }^{1} \mathrm{AB}$ : aerobic bioreactor with activated sludge; ${ }^{2}$ Out: treated wastewater; ${ }^{3} \mathrm{BC} 1$ : bioreactor with biocarriers1; ${ }^{4} \mathrm{BC} 2$ : bioreactor with biocarriers2; ${ }^{5}$ Total: Total

Removal in BC1 and BC2 ; ${ }^{6}$ attached biomass in MBBR-low was measured once; ${ }^{7}$ attached biomass in MBBR-high was measured thrice 
This is a post-print of the manuscript Biodegradation of benzotriazoles and hydroxy-benzothiazole in wastewater by activated sludge and moving bed biofilm reactor systems. Bioresource Technology. Volume 192, September 2015, Pages 627-635 The publishers version is available from: http://dx.doi.org/10.1016/j.biortech.2015.06.035.

\subsection{Removal of target compounds in continuous-flow systems}

The observed removal of target compounds in each system was mainly due to biodegradation as the compounds are known not to be degraded due to abiotic mechanisms, under the conditions found in bioreactors, and they are poorly sorbed onto biomass (Mazioti et al. 2015). Their average removal varied from 43 to $76 \%$ for BTR, 8 to $69 \%$ for 4TTR, 0 to 53\% for 5TTR, 42 to $49 \%$ for CBTR, 9 to $43 \%$ for XTR and 80 to $97 \%$ for OHBTH (Figure 1), indicating that none of the compounds was totally eliminated during wastewater treatment. Except for CBTR that was removed at the same rate regardless of the treatment type, all other compounds were eliminated to a different degree, depending on the system used.

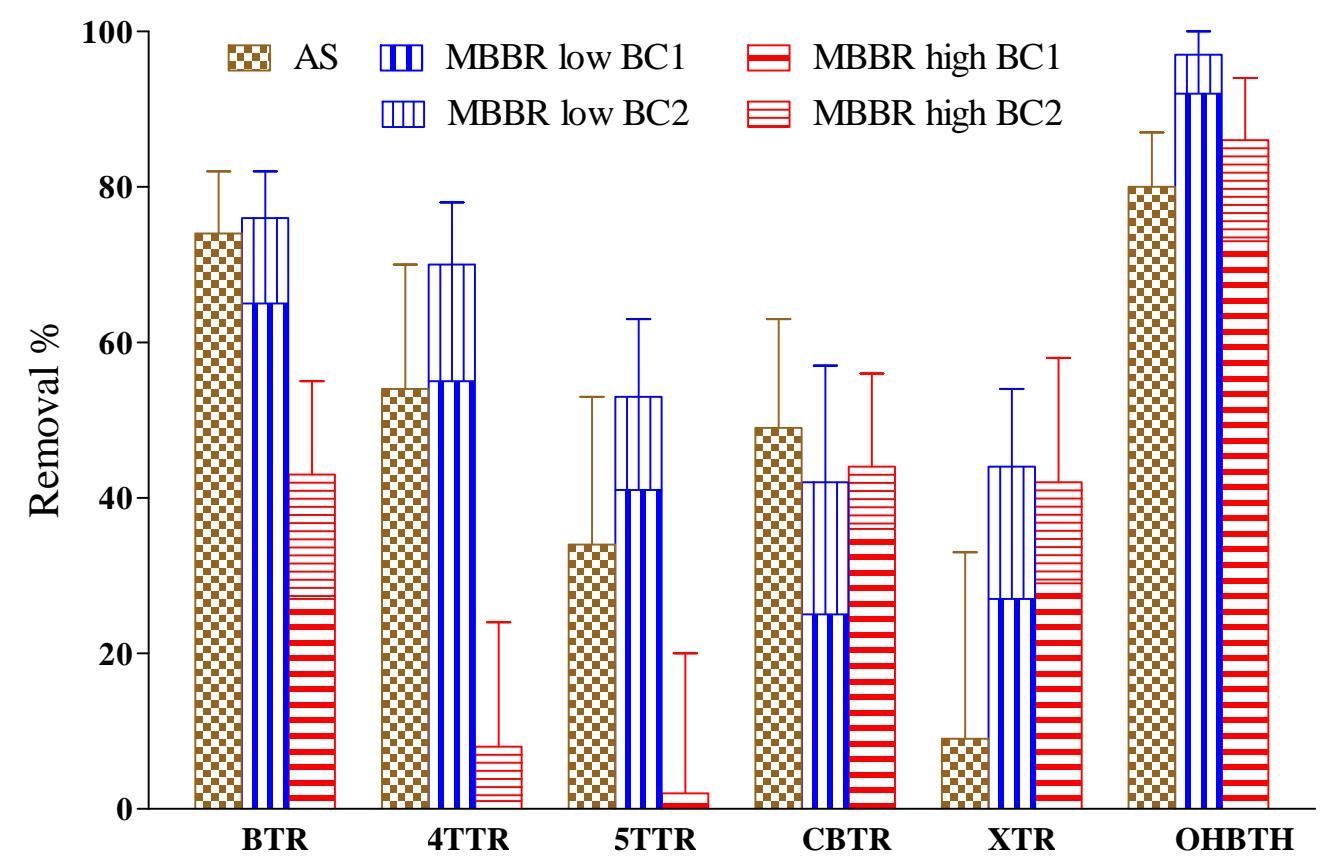

Figure 1: Removal (\%) of target compounds in Activated Sludge (AS) and Moving Bed Biofilm Reactor (MBBR) system operated under low (MBBR-low) and high organic loading (MBBR-high) conditions (tbars represent $95 \%$ confidence interval). The contribution of each bioreactor (BC1 and BC2) to target compounds removal is also shown.

In order to compare the removal efficiency of a suspended-growth and an attached-growth system operating in parallel under the same organic loading conditions and HRT, AS system and BC1 of MBBR-low system were used. According to Figure 1, the removal of 4TTR, 5TTR and XTR was similar in both systems, whereas statistically significant differences were observed for BTR (higher in AS), CBTR (higher in AS) and OHBTH (higher in MBBR), indicating that the application of same organic loading and HRT does not necessarily lead to same removal for all micropollutants. The increase of HRT in the low loaded MBBR system via the addition of a second reactor (BC2) enhanced to some degree the removal of micropollutants (up to 15\%) but complete removal was not achieved. Similarly to the current study, Ahmadi et al. (2015) observed a moderate increase of 
This is a post-print of the manuscript Biodegradation of benzotriazoles and hydroxy-benzothiazole in wastewater by activated sludge and moving bed biofilm reactor systems. Bioresource Technology. Volume 192, September 2015, Pages 627-635 The publishers version is available from: http://dx.doi.org/10.1016/j.biortech.2015.06.035.

diethylphthalate and diallylphthalate removal when HRT was increased from 3 to $12 \mathrm{~h}$ in a MBBR laboratory scale system.

When the MBBR system was operated under a higher organic loading ( $2^{\text {nd }}$ experimental cycle), the total removal of XTR and CBTR was the same with low loaded MBBR. On the other hand, statistically lower removal was observed for OHBTH, BTR, 4TTR, while 5TTR was not eliminated at all (Figure 1). Beside the increased biomass developed in high loaded MBBR (Table 1), it seems that the increase of the organic loading in the MBBR system decreased its capacity to remove some of the target compounds. So far, limited results have been published in the literature for the role of organic loading on the removal of micropollutants. Ahmadi et al. (2015) reported that the increase of organic loading from 0.73 to $1.46 \mathrm{~kg} \mathrm{COD} \mathrm{m}^{-3} \mathrm{~d}^{-1}$ had not actual effect $(<1 \%)$ on the removal of two phthalic acid esters in a MBBR. To the best of our knowledge, no other studies are available in the literature for the range of organic loadings applied in the current study $\left(0.25\right.$ to $0.60 \mathrm{~kg} \mathrm{~m}^{-3}$ $\mathrm{d}^{-1}$ ) and for the added concentrations of micropollutants ( $\mu \mathrm{g} \mathrm{L}^{-1}$ levels).

\subsection{Ability of different types of biomass to biodegrade target compounds}

As the biomass amount was not the same in all bioreactors (Table 1), the specific removal rate (as $\mu$ g per $g$ and day) was calculated for each micropollutant to compare the ability of biomass developed in each system to remove the target compounds. According to the results presented in Table 2 for total specific removal rate, the attached biomass developed in MBBR systems presented statistically significant higher ability to biodegrade all target compounds comparing to the suspended biomass of AS system. In the low loaded MBBR system, these values ranged between 4.6 (XTR) to $11.3 \mu \mathrm{g} \mathrm{g}^{-1} \mathrm{~d}^{-1}$ (BTR), while similar (for OHBTH, XTR, CBTR) or lower values (for BTR and 5TTR) were calculated in high loaded MBBR system. This general advantage of the attached biomass over the suspended is probably due to the higher residence time of biomass onto carriers that could allow a richer biodiversity through the protection of slow growing bacteria from washout, which might be capable to remove micropollutants. In a recent study, Zhang et al. (2015) observed significant differences on the microbial communities established in suspended and attached biomass on phylum and genus level. Moreover, Edwards and Kjellerup (2013) reported that a large variety of species of microorganisms is included in biofilms, whereas all of them contribute to each other's metabolic needs.

To investigate whether biomass with the same ability to remove our target compounds is grown in different bioreactors of the MBBR system, specific removal rates were also calculated for BC1 and BC2 of both MBBR systems (Figure 2, Table S2). For biomass developed under poor organic loading conditions (MBBR-low), three compounds (BTR, 4TTR and 5TTR) had no different specific removal rate between BC1 and BC2. On the other hand, CBTR and XTR were more efficiently removed in BC2, while for OHBTH the first reactor was more effective. It is worth mentioned that the low removal observed for OHBTH in BC2 could be attributed to the low availability of this compound in this reactor (due to its significant removal in BC1) and not necessarily to the capacity of the biomass. A different trend was observed with biomass originating from the high loaded MBBR

(MBBR-high). CBTR, XTR and OHBTH had no differences when comparing the potential of BC1 and BC2, while biomass in the second bioreactor had statistically significant greater ability to remove BTR (in MBBR-high, the specific removal rate for 4TTR and 5TTR could not be calculated in BC1). These results indicate that biomass with different ability to 
This is a post-print of the manuscript Biodegradation of benzotriazoles and hydroxy-benzothiazole in wastewater by activated sludge and moving bed biofilm reactor systems. Bioresource Technology. Volume 192, September 2015, Pages 627-635 The publishers version is available from: http://dx.doi.org/10.1016/j.biortech.2015.06.035.

remove micropollutants can be developed in each bioreactor of a MBBR system and BC2 seem to have a significant role in the development of microorganisms with higher capability to biodegrade micropollutants. It is known that the development of attached biomass is strongly affected by the wastewater characteristics $(\mathrm{pH}$, temperature, type of bioavailable organic compounds, abundance of nutrients) and the operational conditions of the system (organic loading, aeration rate). The existence of low concentrations of micropollutants could also affect bacterial behaviour. In a recent study, it was reported that even small concentration of a xenobiotic compound $\left(0.1 \mu \mathrm{g} \mathrm{L}^{-1}\right.$ for PFOA and PFOS and $0.5 \mu \mathrm{g} \mathrm{L}^{-1}$ for triclosan) can provoke increase of extracellular polymers (EPS) in sludge, therefore affecting the transfer of substances from the mixed liquor to the interior of the flocs or the biofilm (Pasquini et al., 2013). This could decrease the amount of micropollutants available to microorganisms and therefore decrease their removal.

Table 2. Mass of micropollutants removed per mass of biomass and day during continuous flow experiments with Activated Sludge (AS), Biocarriers under low loading conditions (MBBR-low) and Biocarriers under high loading conditions (MBBR-high) (values in bold indicate statistically significant differences).

\begin{tabular}{|c|c|c|c|c|c|c|}
\hline \multirow{2}{*}{ System } & \multicolumn{6}{|c|}{ Specific removal ( $\mu \mathrm{g}$ of micropollutant removed per $\mathrm{g}$ of biomass per day) } \\
\hline & BTR & 4TTR & 5TTR & CBTR & XTR & OHBTH \\
\hline AS & $5.7( \pm 1.8)$ & $4.2( \pm 1.6)$ & $3.9( \pm 1.9)$ & $3.0( \pm 1.0)$ & $0.7( \pm 1.1)$ & $5.4( \pm 1.6)$ \\
\hline MBBR-low & $11.3( \pm 1.6)$ & $9.9( \pm 3.2)$ & $10.9( \pm 2.8)$ & $5.2( \pm 1.9)$ & $4.6( \pm 1.1)$ & $11.5( \pm 1.2)$ \\
\hline MBBR-high & $5.7( \pm 1.9)$ & $15.1( \pm 12.3)$ & $6.1( \pm 5.3)$ & $6.5( \pm 2.0)$ & $4.4( \pm 1.9)$ & $11.6( \pm 2.6)$ \\
\hline
\end{tabular}


This is a post-print of the manuscript Biodegradation of benzotriazoles and hydroxy-benzothiazole in wastewater by activated sludge and moving bed biofilm reactor systems. Bioresource Technology. Volume 192, September 2015, Pages 627-635 The publishers version is available from: http://dx.doi.org/10.1016/j.biortech.2015.06.035.
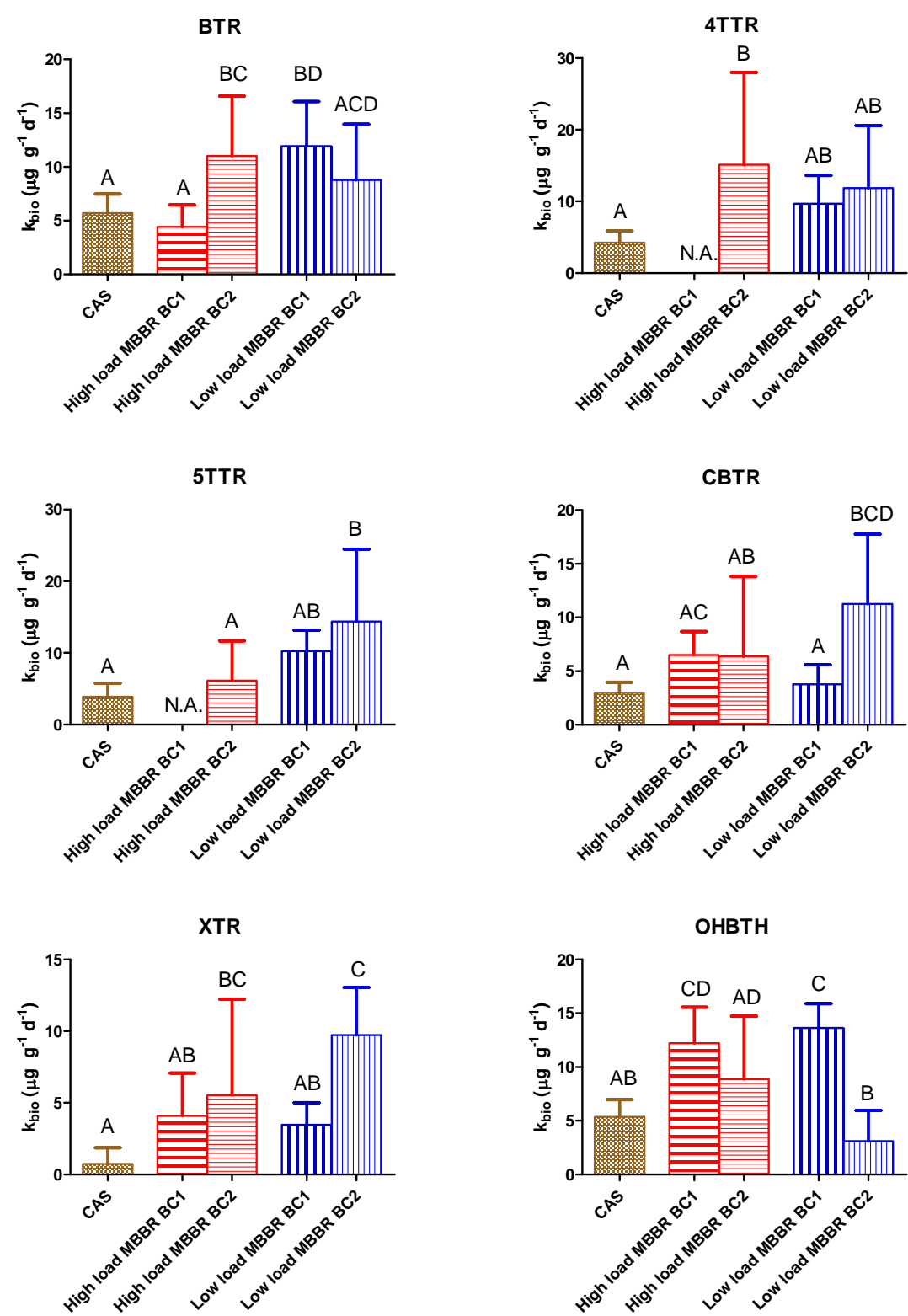

Figure 2: Mass of micropollutants removed per mass of biomass and day during continuous flow experiments with Activated Sludge (AS), Biocarriers under low loading conditions (MBBR-low) and Biocarriers under high loading conditions (MBBR-high). Results are given for each bioreactor (BC1 and BC2), separately (different letters indicate statistical differences at 95\% confidence level; t-bars represent 95\% confidence interval).

\subsection{Effect of substrate on biodegradation kinetics}

To investigate the role of substrate on biodegradation of target compounds, batch experiments were conducted and biodegradation constants were calculated under high and low COD concentrations (Figure 3, Table S3). 
This is a post-print of the manuscript Biodegradation of benzotriazoles and hydroxy-benzothiazole in wastewater by activated sludge and moving bed biofilm reactor systems. Bioresource Technology. Volume 192, September 2015, Pages 627-635 The publishers version is available from: http://dx.doi.org/10.1016/j.biortech.2015.06.035.

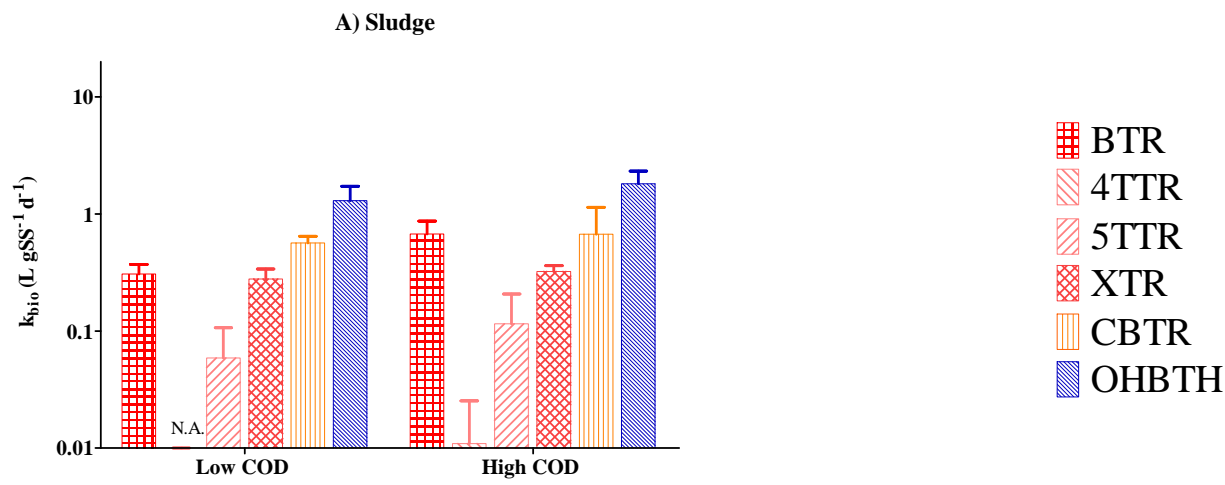

B) First stage biofilm

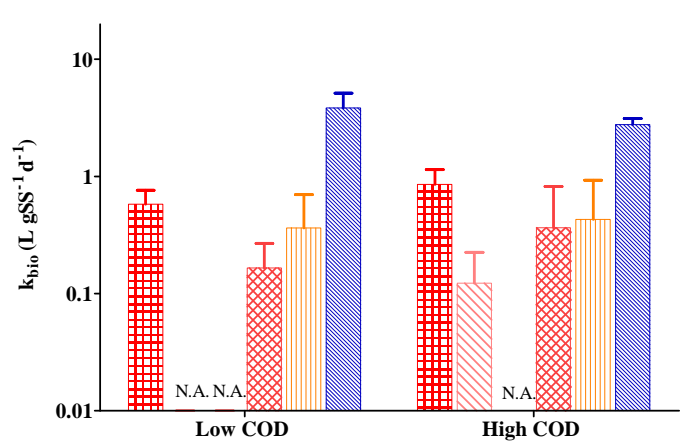

C) Second stage biofilm

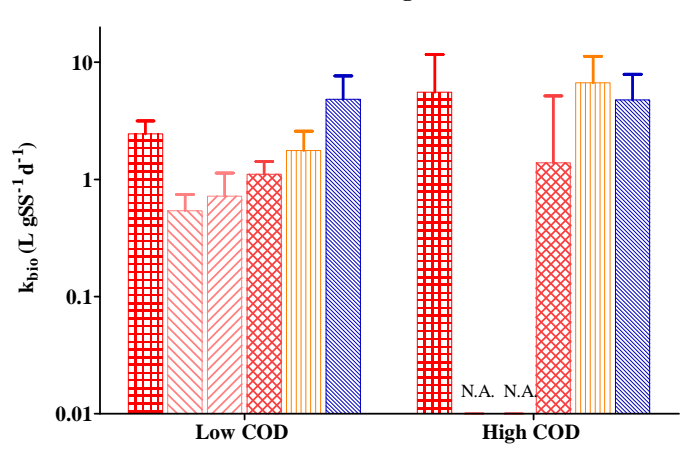

Figure 3: Effect of low or high COD concentrations on observed biodegradation constants, $k_{\text {bio }}\left(\mathrm{L} \mathrm{gss}^{-1} \mathrm{~d}^{-1}\right)$ in batch experiments with activated sludge (A) and attached biomass from BC1 (B) and BC2 (C) (t-bars represent 95\% confidence interval).

For the AS experiment, the biomass used was not taken from the continuous flow system but from the local municipal STP operated at the same SRT (18 d) in order to be able to perform the batch experiment at the same time as the experiment with biomass from the high load MBBR. The biodegradation constants $\left(\mathrm{k}_{\mathrm{bio}}\right)$ calculated for BTR, CBTR, XTR and OHBTH were in the same range as the values found for AS in our previous work (Mazioti et al. 2015). The increased substrate concentration resulted in increased biodegradation (Figure 3A), indicating that biodegradation of the target compounds in AS is due to cometabolism by microorganisms utilizing a wide range of carbon sources. Similar observations for the role of co-metabolism have already been reported in previous studies (Huntscha et al. 2014; Mazioti et al., 2015). Biodegradation constants for 4TTR and 5TTR were generally very low during the experiment $(24 \mathrm{~h})$. This is in agreement with our previous work (Mazioti et al. 2015) but contradict the ability of the continuous-flow AS system used in this study to degrade these compounds. In the literature, contradictive results have been reported for the biodegradation potential of these two compounds in AS systems. Weiss et al. (2006) and Herzog et al. (2014a) reported no removal of 4TTR during AS process, while Liu et al. (2011) reported that biodegradation of 5TTR was very slow (complete removal after $91 \mathrm{~d}$ ). Huntscha et al. (2014) reported half-lives of $8.5 \mathrm{~d}$ and $0.9 \mathrm{~d}$ for 4TTR and 5TTR, respectively. Having in mind that factors such as SRT and increase of 
This is a post-print of the manuscript Biodegradation of benzotriazoles and hydroxy-benzothiazole in wastewater by activated sludge and moving bed biofilm reactor systems. Bioresource Technology. Volume 192, September 2015, Pages 627-635 The publishers version is available from: http://dx.doi.org/10.1016/j.biortech.2015.06.035.

substrate concentration do not seem to explain the differences observed in biodegradation of these two compounds, there is need for further research on the characteristics of biomass and the specific groups of microorganisms involved in their removal.

Concerning the attached biomass, to the best of our knowledge, no biodegradation constants have been calculated for the target compounds so far. First order degradation constants (k) were in the same range with constants calculated for AS (Table S3, Figure S4). When normalized to the concentration of biomass, the biodegradation constants $\left(\mathrm{k}_{\mathrm{bio}}\right)$ for the attached biomass were higher, especially for biomass originated from BC2 whereas the concentration of solids was lower (Table S3). Among target compounds, the highest $\mathrm{k}_{\mathrm{bio}}$ were obtained for CBTR, BTR and OHBTH and were 6.7, 5.6 and $4.8 \mathrm{~L} \cdot \mathrm{gss}^{-1} \cdot \mathrm{d}^{-1}$, respectively. Regarding the role of COD on biodegradation kinetics, similarly to AS experiments, the increase of COD enhanced biodegradation of target compounds (Figure 3B, C). These results indicate that co-metabolic phenomena are also responsible for the biodegradation of target compounds in attached biomass systems.

\subsection{Comparing calculated and predicted removal efficiencies}

To investigate how well batch biodegradation kinetics predict the removal of target compounds in continuous-flow systems, Equation 4 was used to predict the removal of each target compound and the predicted removal efficiencies are compared with measured removal efficiencies as shown in Figure 4. The predicted removal by AS was very close to the observed removal for CBTR and OHBTH. For XTR, the measured removal was much lower than the predicted, while on the other hand BTR was actually removed at a higher extent (74\%) than predicted (35\% and 55\%). Little removal was predicted for 4TTR and 5TTR which is quite different from that is observed in the continuous-flow system (Figure 4A). The differences might be due to the fact that the biomass used in batch experiments for the calculation of kinetics was not the same as that used in the continuous flow experiment. These observations indicate that for 4 out of 6 target compounds, care should be given on batch biodegradation kinetics used for predicting their removal in full-scale systems, as the origin of biomass seem to affect the results.

Among MBBR systems, as it was expected, better prediction was achieved for MBBR-high as the biomass used for batch and continuous-flow experiments was the same. Specifically, the behaviour of BTR, 4TTR, 5TTR and OHBTH was predicted sufficiently, while minor fluctuations were observed for CBTR and XTR (Figure 4C). Regarding MBBR-low system, the use of Equation 4 predicted sufficiently 3 out of 6 (BTR, XTR, OHBTH). However, significant differences were observed especially for 4TTR and 5TTR (Figure 4B). 
This is a post-print of the manuscript Biodegradation of benzotriazoles and hydroxy-benzothiazole in wastewater by activated sludge and moving bed biofilm reactor systems. Bioresource Technology. Volume 192, September 2015, Pages 627-635 The publishers version is available from: http://dx.doi.org/10.1016/j.biortech.2015.06.035.

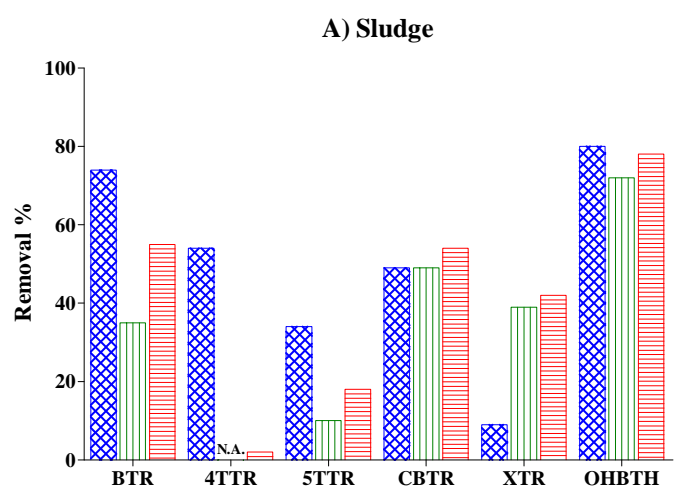

Meassured

IIII Calculated Low COD

咒 Calculated High COD

B) MBBR low

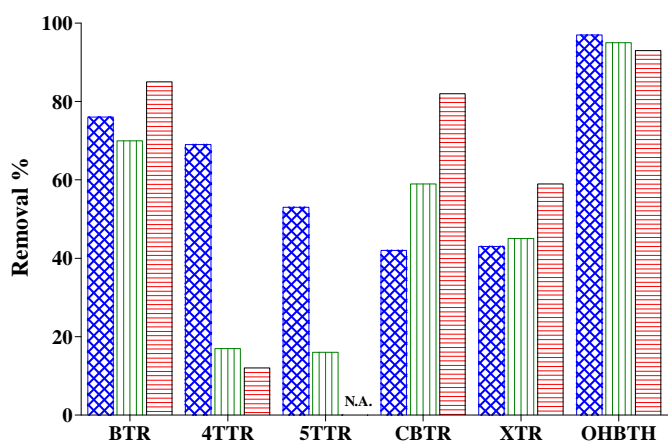

C) MBBR high

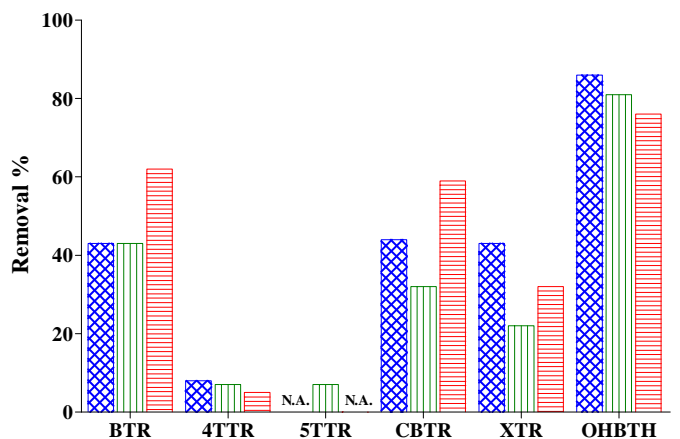

Figure 4 : Measured and calculated removal in AS (A), MBBR-low (B) and MBBR-high system (C).

\section{Conclusions}

Both AS and MBBR system were able to biodegrade the target compounds. Removal efficiencies ranged from 43 to $76 \%$ for BTR, 8 to $69 \%$ for 4 TTR, 0 to $53 \%$ for 5 TTR, 42 to 49\% for CBTR, 9 to $43 \%$ for XTR and 80 to 97\% for OHBTH. The biomass developed in the MBBR system had greater capacity for removal, especially when operated under low organic loading. The presence of easily degradable organic matter enhanced biodegradation of compounds in batch tests. Further research is needed especially for 4TTR and 5TTR, focusing on specific microorganisms that could be responsible for their biodegradation.

\section{Acknowledgments}

This research has been co-financed by the European Union (European Social Fund - ESF) and Greek national funds through the Operational Program "Education and Lifelong Learning" of the National Strategic Reference Framework (NSRF) - Research Funding Program: THALES. Investing in knowledge society through the European Social Fund. (WATERMICROPOL, www.aegean.gr/environment/watermicropol). Biocarriers used in the experiments were kindly provided by AnoxKaldnes, Lund, Sweden. Athanasios 
This is a post-print of the manuscript Biodegradation of benzotriazoles and hydroxy-benzothiazole in wastewater by activated sludge and moving bed biofilm reactor systems. Bioresource Technology. Volume 192, September 2015, Pages 627-635 The publishers version is available from: http://dx.doi.org/10.1016/j.biortech.2015.06.035.

Stasinakis would like to thank DTU (Department of Environmental Engineering) for hosting him during the period that this article was written.

\section{References}

1. Accinelli, C., Saccà, M.L., Mencarelli, M., Vicari, A., 2012. Application of bioplastic moving bed biofilm carriers for the removal of synthetic pollutants from wastewater. Bioresour. Technol. 120, 180-186.

2. Ahmadi, E., Gholami, M., Farzadkia, M., Nabizadeh, R., Azari, A., 2015. Study of moving bed biofilm reactor in diethyl phthalate and diallyl phthalate removal from synthetic wastewater. Bioresour. Technol. 183, 129-135.

3. APHA, 1998. Standard methods: for the examination of water and wastewater, American Public Health Association, $20^{\text {th }}$ edition

4. Asimakopoulos, A.G., Ajibola, A., Kannan, K., and Thomaidis, N.S., 2013. Occurrence and removal efficiencies of benzotriazoles and benzothiazoles in a wastewater treatment plant in Greece. Sci. Total Environ. 452-453, 163-171.

5. Barwal, A., Chaudhary, R., 2014. To study the performance of biocarriers in moving bed biofilm reactor (MBBR) technology and kinetics of biofilm for retrofitting the existing aerobic treatment systems: A review. Rev. Environ. Sci. Biotechnol. 13, 285299.

6. Borghei, S.M., Hosseini, S.H., 2004. The treatment of phenolic wastewater using a moving bed biofilm reactor. Process Biochem. 39, 1177-1181.

7. Di Trapani, D., Christensso, M., Ødegaard, H., 2011. Hybrid activated sludge/biofilm process for the treatment of municipal wastewater in a cold climate region: A case study. Water Sci. Technol. 63, 1121-1129.

8. Edwards, S.J., Kjellerup, B.V., 2013. Applications of biofilms in bioremediation and biotransformation of persistent organic pollutants, pharmaceuticals/personal care products, and heavy metals. Appl. Microbiol. Biotechnol. 97, 9909-9921.

9. Falås, P., Baillon-Dhumez, A., Andersen, H.R., Ledin, A., La Cour Jansen, J., 2012. Suspended biofilm carrier and activated sludge removal of acidic pharmaceuticals. Water Res. 46, 1167-1175.

10. Falås, P., Longrée, P., La Cour Jansen, J., Siegrist, H., Hollender, J., Joss, A., 2013. Micropollutant removal by attached and suspended growth in a hybrid biofilm-activated sludge process. Water Res. 47, 4498-4506.

11. Gilbert, E.M., Agrawal, S., Karst, S.M., Horn, H., Nielsen, P.H., Lackner, S., 2014. Low temperature partial nitritation/anammox in a moving bed biofilm reactor treating low strength wastewater. Environ. Sci. Technol. 48, 8784-8792.

12. Herzog, B., Lemmer, H., Huber, B., Horn, H., Müller, E., 2014a. Xenobiotic benzotriazoles-biodegradation under meso- and oligotrophic conditions as well as denitrifying, sulfate-reducing, and anaerobic conditions. Environ. Sci. Pollut. Res. 21, 2795-2804.

13. Herzog, B., Yuan, H., Lemmer, H., Horn, H., Muller, E., 2014b. Effect of acclimation and nutrient supply on 5-tolyltriazole biodegradation with activated sludge communities. Bioresour. Technol. 163, 381-385. 
This is a post-print of the manuscript Biodegradation of benzotriazoles and hydroxy-benzothiazole in wastewater by activated sludge and moving bed biofilm reactor systems. Bioresource Technology. Volume 192, September 2015, Pages 627-635 The publishers version is available from: http://dx.doi.org/10.1016/j.biortech.2015.06.035.

14. Huntscha, S., Hofstetter, T.B., Schymanski, E.L., Spahr, S., Hollender, J., 2014. Biotransformation of benzotriazoles: Insights from transformation product identification and compound-specific isotope analysis. Environ. Sci. Technol. 48, 4435-4443.

15. Ibrahim, H.T., Qiang, H., Al-Rekabi, W.S., 2014. Simultaneous organics and nutrients removal from domestic wastewater in a combined cylindrical anoxic/aerobic moving bed biofilm reactor. Res. J. Appl. Sci., Eng. Technol. 7, 1887-1895.

16. Jenkins, D., Richard, M.G., Daigger, G.T., 2003. Manual on the causes and control of activated sludge bulking, foaming, and other solids separation problems. Lewis Publishers, $3^{\text {rd }}$ edition.

17. Khan, M.M.T., Chapman, T., Cochran, K., Schuler, A.J., 2013. Attachment surface energy effects on nitrification and estrogen removal rates by biofilms for improved wastewater treatment. Water Res. 47, 2190-2198.

18. Liu, Y.-S., Ying, G.-G., Shareef, A., Kookana, R.S., 2011. Biodegradation of three selected benzotriazoles under aerobic and anaerobic conditions. Water Res. 45, 50055014.Liu, Y.-S., Ying, G.-G., Shareef, A., Kookana, R.S., 2012. Occurrence and removal of benzotriazoles and ultraviolet filters in a municipal wastewater treatment plant. Environ. Pollut. 165, 225-232.

19. Loos, R., Gawlik, B.M., Locoro, G., Rimaviciute, E., Contini, S., Bidoglio, G., 2009. EU-wide survey of polar organic persistent pollutants in European river waters. Environ. Pollut. 157, 561-568.

20. Loupasaki, E., Diamadopoulos, E., 2013. Attached growth systems for wastewater treatment in small and rural communities: A review. J. Chem. Technol. Biotechnol. 88, 190-204.

21. Luo, Y., Guo, W., Ngo, H.H., Nghiem, L.D., Hai, F.I., Kang, J., Xia, S., Zhang, Z., Price, W.E., 2014. Removal and fate of micropollutants in a sponge-based moving bed bioreactor. Bioresour. Technol. 159, 311-319.

22. Mazioti, A.A., Stasinakis, A.S., Gatidou, G., Thomaidis, N.S., Andersen, H.R., 2015, Sorption and biodegradation of selected benzotriazoles and hydroxybenzothiazole in activated sludge and estimation of their fate during wastewater treatment. Chemosphere 131, 117-123.

23. Ni, H.-G., Lu, F.-H., Luo, X.-L., Tian, H.-Y., Zeng, E.Y., 2008. Occurrence, phase distribution, and mass loadings of benzothiazoles in riverine runoff of the Pearl River Delta, China. Environ. Sci. Technol. 42, 1892-1897.

24. Nödler, K., Voutsa, D., Licha, T., 2014. Polar organic micropollutants in the coastal environment of different marine systems. Mar. Pollut. Bull. 85, 50-59.

25. Pasquini, L., Merlin, C., Hassenboehler, L., Munoz, J.-F., Pons, M.-N., Görner, T., 2013. Impact of certain household micropollutants on bacterial behavior. Toxicity tests/study of extracellular polymeric substances in sludge. Sci. Total Environ. 463-464, 355-365.

26. Reemtsma, T., Miehe, U., Duennbier, U., Jekel, M., 2010. Polar pollutants in municipal wastewater and the water cycle: Occurrence and removal of benzotriazoles. Water Res. 44, 596-604.

27. Shahot, K., Idris, A., Omar, R., Yusoff, H.M., 2014. Review on biofilm processes for wastewater treatment. Life Sci. J. 11, 1-13.

28. Stasinakis, A.S., Thomaidis, N.S., Arvaniti, O.S., Asimakopoulos, A.G., Samaras, V.G., Ajibola, A., Mamais, D., Lekkas, T.D., 2013. Contribution of primary and 
This is a post-print of the manuscript Biodegradation of benzotriazoles and hydroxy-benzothiazole in wastewater by activated sludge and moving bed biofilm reactor systems. Bioresource Technology. Volume 192, September 2015, Pages 627-635 The publishers version is available from: http://dx.doi.org/10.1016/j.biortech.2015.06.035.

secondary treatment on the removal of benzothiazoles, benzotriazoles, endocrine disruptors, pharmaceuticals and perfluorinated compounds in a sewage treatment plant. Sci. Total Environ. 463-464, 1067-1075.

29. Thomaidis, N.S., Asimakopoulos, A.G., Bletsou A.A., 2012. Emerging contaminants: A tutorial mini-review. Global Nest J. 14, 72-79.

30. Weiss, S., Jakobs, J., Reemtsma, T., 2006. Discharge of three benzotriazole corrosion inhibitors with municipal wastewater and improvements by membrane bioreactor treatment and ozonation. Environ. Sci. Technol. 40, 7193-7199.

31. Zhang, S., Wang, Y., He, W., Wu, M., Xing, M., Yang, J., Gao, N., Pan, M., 2014. Impacts of temperature and nitrifying community on nitrification kinetics in a moving-bed biofilm reactor treating polluted raw water. Chem. Eng. J. 236, 242-250.

32. Zhang, P., Guo, J.S., Shen, Y., Yan, P., Chen, Y.P., Wang, H., Yang, J.X., Fang, F., Li, C., 2015. Microbial communities, extracellular proteomics and polysaccharides: A comparative investigation on biofilm and suspended sludge. Bioresesour. Technol. 190, 21-28.

33. Ziels, R.M., Lust, M.J., Gough, H.L, Strand, S.E., Stensel, H.D., 2014. Influence of bioselector processes on $17 \alpha$-ethinylestradiol biodegradation in activated sludge wastewater treatment systems. Environ. Sci. Technol. 48, 6160-6167. 


\section{Supplementary material}

\section{Biodegradation of benzotriazoles and hydroxy-benzothiazole in wastewater by activated sludge and moving bed biofilm reactor systems}

Aikaterini A. Mazioti ${ }^{\mathrm{a}}$, Athanasios S. Stasinakis ${ }^{\mathrm{a}, \mathrm{b}^{*}}$, Ypapanti Pantazi $^{\mathrm{a}}$, Henrik R. Andersen ${ }^{\mathrm{b}}$

${ }^{\mathrm{a}}$ Department of Environment, University of the Aegean, Mytilene, Greece

${ }^{\mathrm{b}}$ Department of Environmental Engineering, Technical University of Denmark, Miljøvej, B 113, 2800 Kgs. Lyngby, Denmark

*Corresponding author. Tel.: +30 22510 36257; fax: +30 2251036206

E-mail address: astas@env.aegean.gr

The following tables and figures are included as supplementary information for this paper:

Number of tables: 3

Number of figures: 4 
Table S1. Characteristics of raw wastewater used in the current study ( $\mathrm{n}=30$, standard deviations are given in parentheses).

\begin{tabular}{|c|c|}
\hline Parameter & Value \\
\hline $\mathrm{pH}$ & $7.3( \pm 0.3)$ \\
\hline $\mathrm{COD}_{\text {dis }}\left(\mathrm{mg} \mathrm{L}^{-1}\right)$ & $272( \pm 179)$ \\
\hline $\mathrm{NH}_{4}-\mathrm{N}\left(\mathrm{mg} \mathrm{L}^{-1}\right)$ & $50( \pm 16)$ \\
\hline $\mathrm{NO}_{3}-\mathrm{N}\left(\mathrm{mg} \mathrm{L}^{-1}\right)$ & $3.2( \pm 2.5)$ \\
\hline $\mathrm{TSS}\left(\mathrm{mg} \mathrm{L}^{-1}\right)$ & $86( \pm 44)$ \\
\hline
\end{tabular}


Table S2. Mass of micropollutants removed per mass of biomass and day during continuous flow experiments with Biocarriers under low loading conditions (MBBR-low) and Biocarriers under high loading conditions (MBBR-high) in each bioreactor (BC1 and BC2). Removal of 4TTR and 5TTR in MBBR-low (BC1) was very low and the relevant values were not calculated (N.A.).

\begin{tabular}{|c|c|c|c|c|c|c|c|}
\hline \multicolumn{2}{|c|}{ System/Reactor } & \multicolumn{6}{|c|}{ Specific removal ( $\mu \mathrm{g}$ of micropollutant removed per g of biomass per day) } \\
\hline & & BTR & 4TTR & 5TTR & CBTR & XTR & OHBTH \\
\hline \multirow{2}{*}{$\begin{array}{c}\text { MBBR- } \\
\text { low }\end{array}$} & BC1 & $11.9( \pm 1.3)$ & $9.7( \pm 3.6)$ & $10.3( \pm 2.8)$ & $3.9( \pm 1.7)$ & $3.5( \pm 1.6)$ & $13.6( \pm 2.2)$ \\
\hline & BC2 & $8.8( \pm 4.6)$ & $11.9( \pm 8.5)$ & $14.4( \pm 9.9)$ & $11.3( \pm 6.5)$ & $9.7( \pm 3.3)$ & $3.1( \pm 2.6)$ \\
\hline \multirow{2}{*}{$\begin{array}{c}\text { MBBR- } \\
\text { high }\end{array}$} & BC1 & $4.4( \pm 2.0)$ & N.A. & N.A. & $6.5( \pm 2.1)$ & $4.1( \pm 2.9)$ & $12.2( \pm 3.2)$ \\
\hline & BC2 & $11.0( \pm 5.3)$ & $15.1( \pm 12.3)$ & $6.1( \pm 5.3)$ & $6.4( \pm 7.1)$ & $5.5( \pm 6.4)$ & $8.9( \pm 5.6)$ \\
\hline
\end{tabular}


Table S3. Biodegradation constants calculated during batch experiments with suspended and attached biomass, under low and high COD concentrations (average values and standard deviation).

\begin{tabular}{|c|c|c|c|c|c|c|c|c|c|c|c|c|c|}
\hline \multicolumn{14}{|c|}{ Biodegradation rate constant, $\mathrm{k}\left(\mathrm{d}^{-1}\right)$} \\
\hline Experiment & COD & average & st.dev. & average & st.dev. & average & st.dev. & average & st.dev. & average & st.dev. & average & st.dev. \\
\hline & & \multicolumn{2}{|c|}{ BTR } & \multicolumn{2}{|c|}{ 4TTR } & \multicolumn{2}{|c|}{ 5TTR } & \multicolumn{2}{|c|}{ CBTR } & \multicolumn{2}{|c|}{ XTR } & \multicolumn{2}{|c|}{ ОНВТН } \\
\hline $\mathrm{BC} 1^{1}$ & Low $^{4}$ & 0.66 & 0.21 & N.A. & N.A. & N.A. & N.A. & 0.41 & 0.37 & 0.22 & 0.14 & 4.74 & 1.62 \\
\hline $\mathrm{BC}^{1}$ & $\operatorname{High}^{5}$ & 0.98 & 0.33 & 0.15 & 0.12 & N.A. & N.A. & 0.48 & 0.56 & 0.49 & 0.61 & 3.43 & 0.44 \\
\hline $\mathrm{BC}^{2}$ & Low $^{4}$ & 0.90 & 0.26 & 0.20 & 0.08 & 0.27 & 0.16 & 0.64 & 0.30 & 0.43 & 0.12 & 1.82 & 1.06 \\
\hline $\mathrm{BC}^{2}$ & $\operatorname{High}^{5}$ & 2.03 & 2.22 & N.A. & N.A. & N.A. & N.A. & 2.43 & 1.64 & 0.53 & 1.46 & 1.78 & 1.17 \\
\hline $\mathrm{AB}^{3}$ & Low $^{4}$ & 0.50 & 0.11 & N.A. & N.A. & 0.11 & 0.09 & 0.90 & 0.13 & 0.58 & 0.12 & 2.41 & 0.78 \\
\hline $\mathrm{AB}^{3}$ & $\operatorname{High}^{5}$ & 1.11 & 0.32 & 0.02 & 0.01 & 0.21 & 0.16 & 1.07 & 0.74 & 0.68 & 0.08 & 3.36 & 0.94 \\
\hline \multicolumn{14}{|c|}{ Pseudo first-order biodegradation rate constant, $k_{b i o}\left(\mathrm{~L} \mathrm{~g}_{s s}{ }^{-1} d^{-1}\right)$} \\
\hline \multirow[t]{2}{*}{ Experiment } & COD & average & st.dev. & average & st.dev. & average & st.dev. & average & st.dev. & average & st.dev. & average & st.dev. \\
\hline & & \multicolumn{2}{|c|}{ BTR } & \multicolumn{2}{|c|}{ 4TTR } & \multicolumn{2}{|c|}{ 5TTR } & \multicolumn{2}{|c|}{ CBTR } & \multicolumn{2}{|c|}{ XTR } & \multicolumn{2}{|c|}{ ОНВТН } \\
\hline $\mathrm{BC} 1^{1}$ & Low $^{4}$ & 0.58 & 0.18 & N.A. & N.A. & N.A. & N.A. & 0.36 & 0.33 & 0.17 & 0.10 & 3.84 & 1.31 \\
\hline $\mathrm{BC}^{1}$ & $\operatorname{High}^{5}$ & 0.86 & 0.29 & 0.12 & 0.10 & N.A. & N.A. & 0.43 & 0.50 & 0.37 & 0.46 & 2.78 & 0.35 \\
\hline $\mathrm{BC}^{2}$ & Low $^{4}$ & 2.46 & 0.71 & 0.54 & 0.20 & 0.72 & 0.42 & 1.77 & 0.82 & 1.11 & 0.31 & 4.86 & 2.84 \\
\hline $\mathrm{BC}^{2}$ & $\mathrm{High}^{5}$ & 5.58 & 6.08 & N.A. & N.A. & N.A. & N.A. & 6.72 & 4.54 & 1.39 & 3.81 & 4.77 & 3.14 \\
\hline $\mathrm{AB}^{3}$ & Low $^{4}$ & 0.31 & 0.06 & N.A. & N.A. & 0.06 & 0.05 & 0.57 & 0.08 & 0.28 & 0.06 & 1.30 & 0.42 \\
\hline $\mathrm{AB}^{3}$ & $\operatorname{High}^{5}$ & 0.68 & 0.19 & 0.01 & 0.01 & 0.12 & 0.09 & 0.67 & 0.47 & 0.32 & 0.04 & 1.82 & 0.51 \\
\hline
\end{tabular}


${ }^{1} \mathrm{BC} 1$ : Bioreactor with Biocarriers 1 collected from MBBR high; ${ }^{2} \mathrm{BC} 2$ : Bioreactor with Biocarriers2 collected from MBBR high; ${ }^{3} \mathrm{AB}$ : Aerobic Bioreactor with activated sludge collected from Mytilene's STP; ${ }^{4}$ Low COD: initial concentration: $28( \pm 15) \mathrm{mg} \mathrm{L}^{-1}$; ${ }^{1} \mathrm{High}$ COD: initial concentration: $272( \pm 107) \mathrm{mg} \mathrm{L}^{-1}$ 


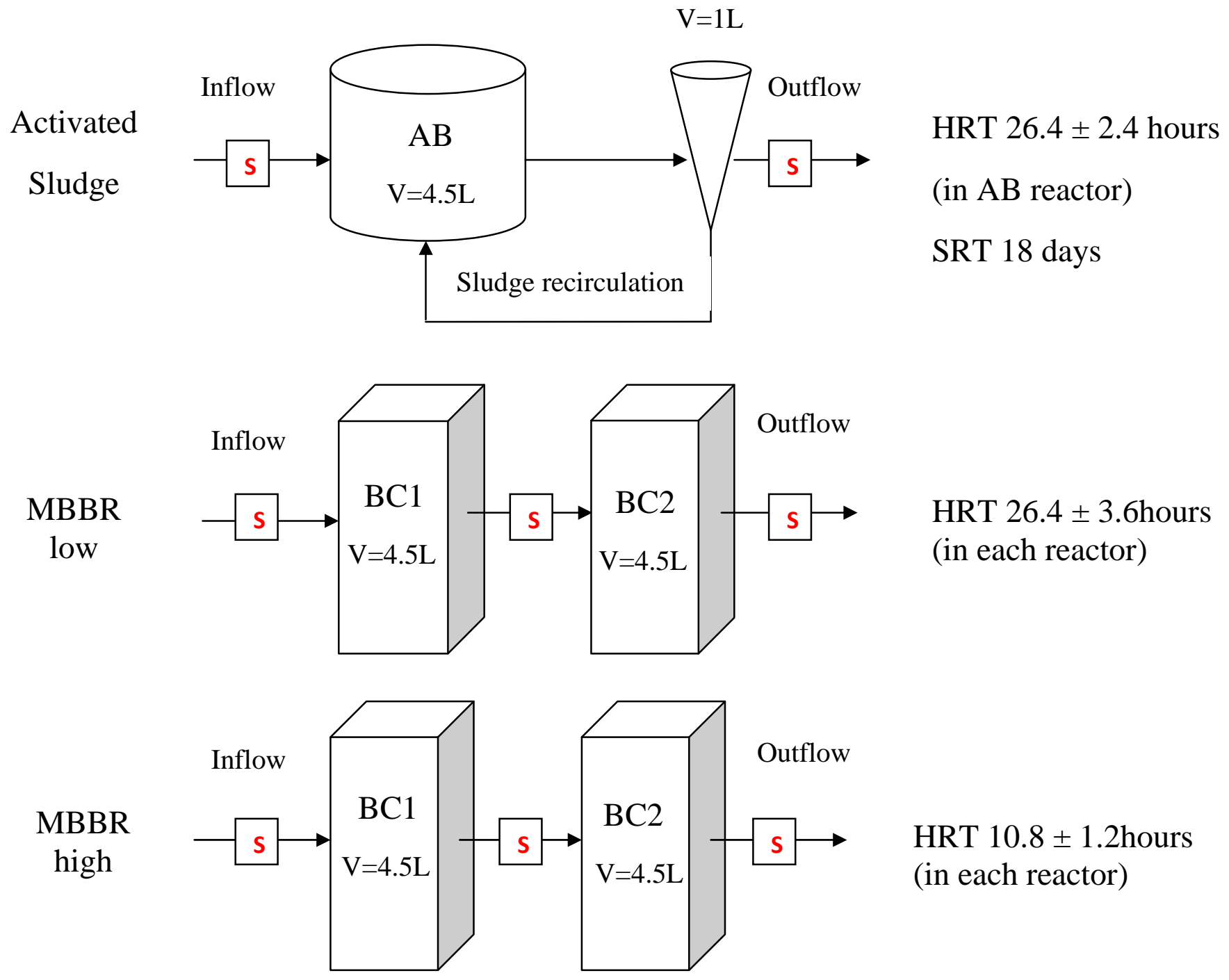

Figure S1. Schematic description of the continuous-flow biological treatment systems used in this study (sampling points are presented with an S). 


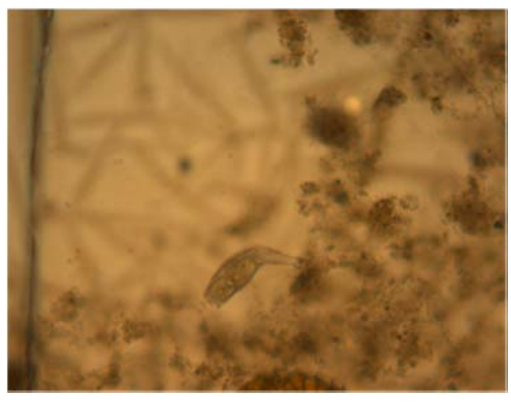

(a)
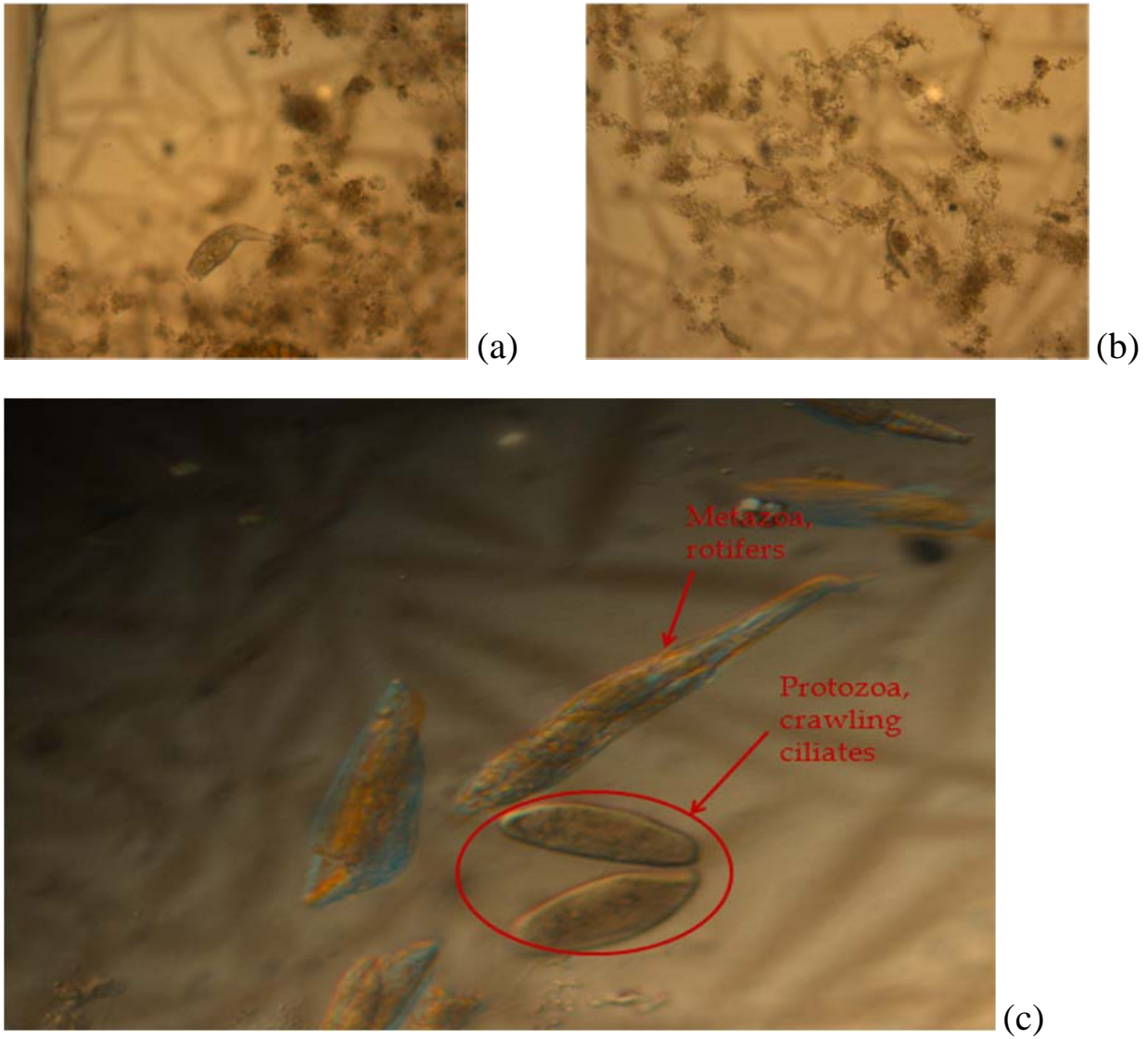

Figure S2. Sample images from the microscopic observations conducted in AS system (a. rotifer, b. filamentous bacteria) and MBBR system (c. rotifers and protozoa). 

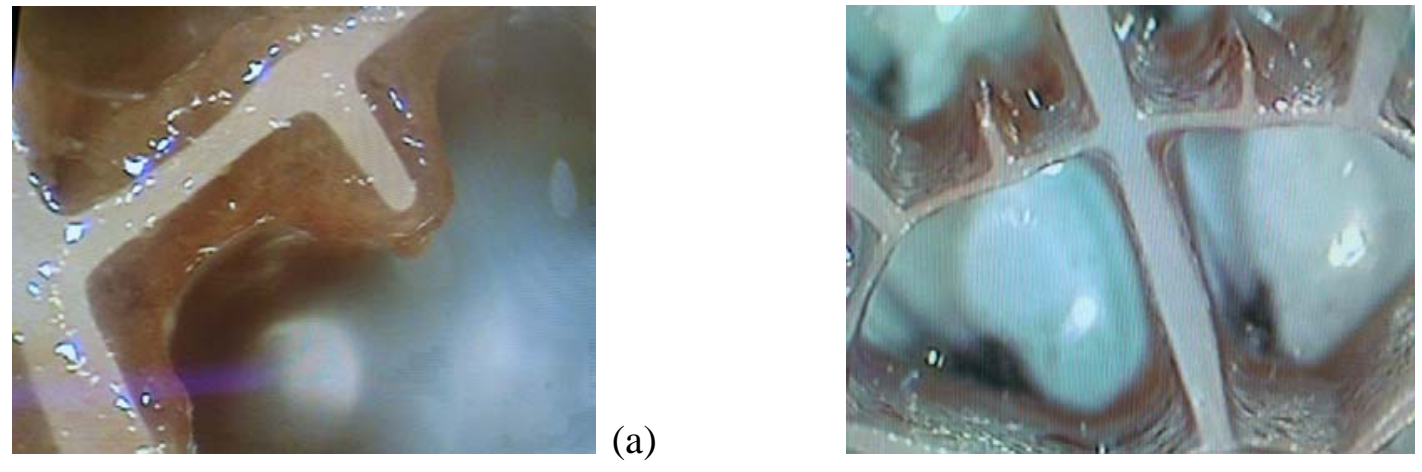

(b)

Figure S3. Biofilm formation on carriers in BC1 (a) and BC2 (b) in the MBBR-low system. 


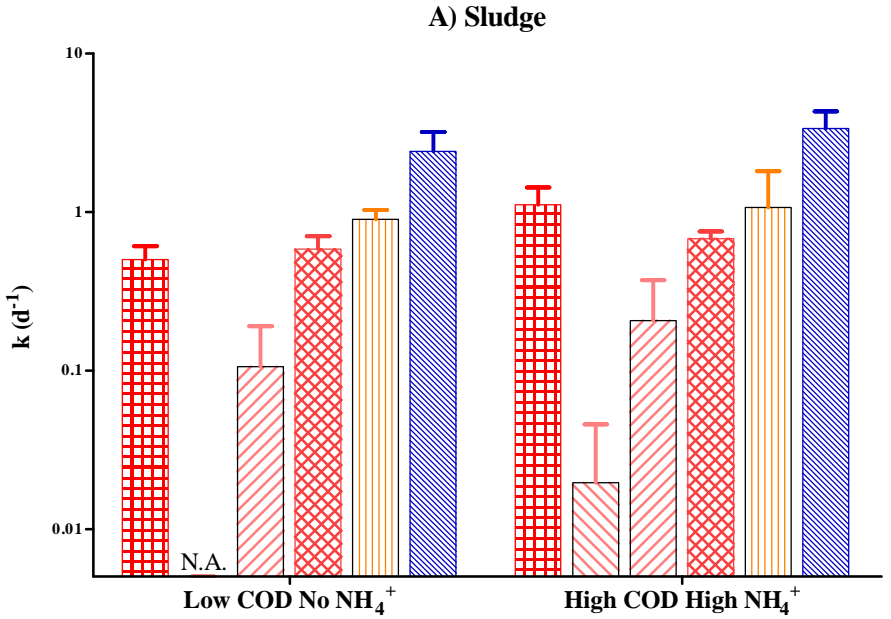

B) First stage biofilm

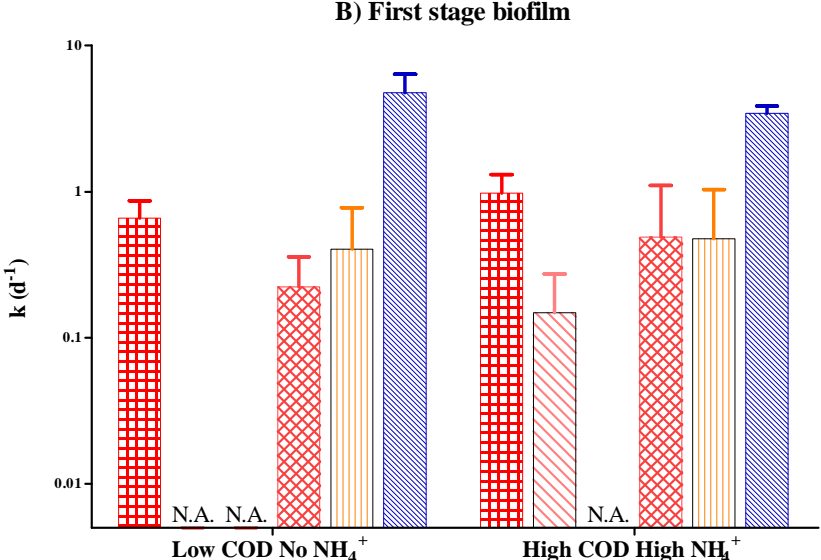
曲 BTR
$\mathbb{Q} 4 \mathrm{TTR}$
团 5 TTR
XTR
四 CBTR
$\mathbb{N}$ OHBTH

C) Second stage biofilm

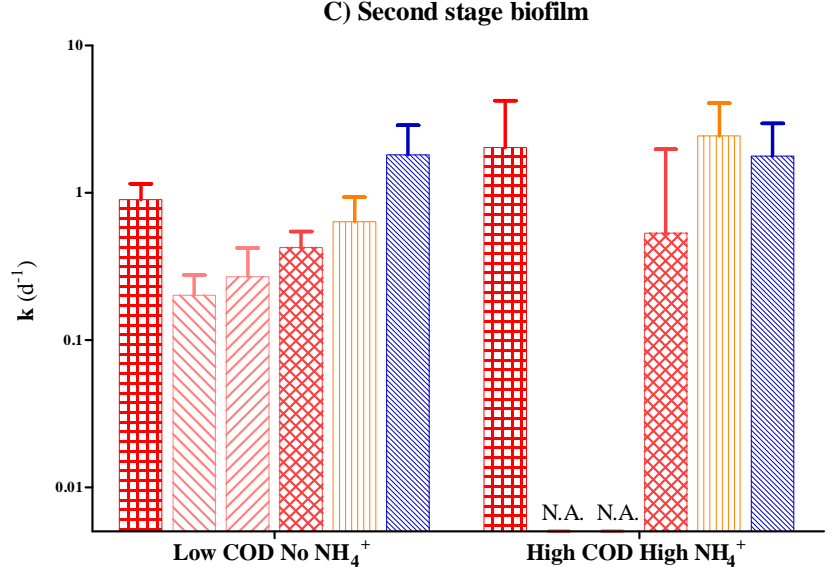

Figure S4. Effect of low or high COD concentrations on observed biodegradation constants, $\mathrm{k}\left(\mathrm{d}^{-1}\right)$ in batch experiments with activated sludge (A) and attached biomass from BC1 (B) and BC2 (C) (t-bars represent 95\% confidence interval). 